\title{
THE TEACHING OF HYGIENE.
}

By Miss S. L. BESZANT.

THE teaching of liygiene, or, as it is generally called, domestic 1 economy, in elementary schools, has considerably improved since the abolition of payment by results. In those bad old days domestic economy was called a specific subject, a bare syllabus of work was arranged in the code, and a grant was paid on indivilual passes. The pass usually consisted of ability to write answers on all kinds of questions, some of which were very remote from the subject. As a result, children were supplied with small, cheap publications on domestic economy; the teacher used them as a kind of reading book, and supplemented them by cramming certain facts into the girls. This so-called teaching of hygiene caused the subject to be looked upon with contempt by scientific men and women, and consequently inspectors, and especially those of schools of science, have discouraged the teaching of the subject. They admit that it has a utilitarian value; but that it has an educative one and that it can afford training in accurate observation, they doubt.

It is because I have paid much attention to the teaching of hygiene and human physiology in an elementary and secondary school that $\mathbf{I}$ venture these few remarks. As I understand the subject, the teaching should consist of :-

I. Experimental demonstrations of scientific principles underlying domestic science.

II. Elementary human physiology taught practically.

III. An elementary knowledge of the composition of food, and more advanced instruction in hygiene.

IV. A practical acquaintance with the applied arts of cookery, cleaning, arrangement of daily work, laundry work, keeping household accounts, sick nursing, ambulance work, the care of young children, and household sewing.

I. It has been frequently urged that inasmuch as hygiene is based upon other sciences, presumably chemistry, plyysics, and animal physiology chiefly, it resolves itself into mechanical book work unless these subjects are taught first. Now the duration of a child's life in an elementary 
school is too short to allow of the teaching of these subjects first, and yet hygiene is too important to be omitted. Clearly, therefore, some other method must be provided which will give the same necessity for accuracy and inductive reasoning as these subjects. It is possible to give simple elementary science lessons with a practical bearing upon lygriene in the standards of an elementary school. In many of the Bradford Board Schools a scheme of this nature has been successfully worked for several years. The following are outlines of the science taught:-

Contrast of solicls and liquids.

Change of state.

Soluble and insoluble bodies.

Evaporation.

Porous and non-porous bodies.

Density.

Effects of heat.

Construction and use of thermometer.

Transmissiun of heat.

Composition of air.

Temporary hard and soft water.

Food.

This work las been successfully taught for several years in Belle Vue Junior and Girls' Departments, Bradford, in Standarls I. to VI. The following method has been adopted :-

1. The teacher has exhibited and allowed the children to handle and examine the objects to be studied, or by means of experiments has shown the phenomena which he has wished the children to notice.

2. The scholars have then been encouraged to describe in their own words, and as minutely as possible, what they have seen, carefully distinguishing between essential and non-essential points.

3. The children have then been led to make simple inferences from the facts observed, such inferences being confirmed or disproved by further experiments until they have arrived at the comprehension of some general truth. The apparatus required is simple and inexpensive. An ordinary class-room supplied with trestle-table, rubber tubing connected with gas pendant, water, etc., is suitable for teaching purposes. In the upper standards a brief summary is written after the lessons.

In small mixed schools where boys and girls are taught togrether, a scheme of elementary hygiene would be as suitable for boys as girls, the applications being extended further to the necessity for labour-saving devices in the house, etc. 
II. Elementary phusiolon! taught practically.-This is an absolute necessity for a thorough srrasp of the principles of hygiene, and should be practical, as there would then be no need for the use of misleading diagrams. In an ordinary elementary school a short course of elementary physiology could be included in standards VI. or VII.

The upper part of Belle Vue Board School has been a science school (now called a secondary school) for six rears. Secing that the teaching of human phrsiology and hygiene had been a feature of the school previously, it was decided to experiment with the teaching of practical physiology as a suitable subject for wirls in place of practical physics. Two old attic class-rooms were converted into a rery satisfactory laboratory, and under the guidance of Mr. Wager, then science inspector for the district, a four years' scheme was worked out. The subject has been treated in a scientific manner: the girls experiment, obscrve, draw inferences, and make their own summaries. The rabbit and frog supply plentry of material, and an intelligent butcher supplements from the slaugliter-houses. The laboratory has been so constructed that the necessary physies and chemistry can be taken. The sulject is popular with the girls, and no squeamislmess or hysteria is shown at the sight of blood, or of a simple disscction. No text books are used by the scholars, but gool books for reference have been supplied to the teachers. I beg to cmplasize here the suitability of practical physiology and hygiene for girls in secondary schools.

III. The physiological syllabus is supplemented by more detailed and adranced hygiene treated experimentally in the advaneed part of the science school. The subjects of food and adulteration, water-supply, the dwelling, including soils and the construction of founclations, sanitary fittings, rentilation, heating, and personal hygiene are dealt with. Visits are paid to buildings in course of erection, \&c.

IV. The revised instructions to inspectors of elementary schools state that "It is not intended that this teaching (practical housewifery) should resolve itself into a class for training clildren for clomestic service, but it is intended to be a course of instruction to fit them on leaving school for the various household duties which devolve more or less upon all women." Hence the need for scientific training to accompany or precede the practical manual work. The teaching of cookery, for example, to girls does not mean restriction to the mere learning of recipes and cooking by rule of thumb. The cookery scheme should include the cost and value of the food materials used, cleaning, setting and decorating the table, and waiting.

A few simple lessons on cleaning, laying, and lighting a fire, the 
structure and mode of action of a gas oven, and cleaning flues, witl simple experiments illustrating the scientific principles underlying such appliances and operations, should likewise be given.

The preparation of regetable and animal food and beverages is taught according to the same plan, a Bunsen burner and a few test tubes affording sufficient apparatus to illustrate the scientific principles. Each day's cooking lesson in the Bradford schools includes the cooking of animal fuod, regetables, and one sweet, so that the cookery does not consist of the making of cakes and toffy.

The teaching of practical cookery has been much appreciated by parents, who have frequently testified to the benefit they have derived from the instruction given. The Bradford school Board are now making preparations for the teaching of practical housewifery in a small house attached to a new school in Green Lane; this, together with laundry and cookery at the same centre, will be in operation during the risit of the Congress to Bradford. Members will be welcomed at the centre as well as at Belle Vue School.

Uncler the new arrangement for practical work, it is probable that girls in standards V. and VI. from four or five schools will attend the Green Lane Domestic Training School in rotation, one half day per week, and a two year's' course to include laundry, cookery, and housewifery will be followed. Where there is a standard VII. I should adrise instruction in more advanced household management, household sewing, the use of the sewing machine, and simple dress-cutting and making.

For several years, instruction in ambulance work and sick nursing las been given by medical men and qualified nurses in the Board's evening schools.

In order that the teaching of hygiene in schools may be a success, there must be:-

1. Sympathy between parents and teachers.

2. Sympatlyy between the teachers in the day schools, and the teachers of practical work.

3. A training in practical elementary science, practical plyysiologry and lyygiene in all training colleges for teachers.

There must necessarily be expense, but if the results are an improvement in the general health, happiness, and moral tone of the community, a love for home life, and a lowering in the deatll-rate of young children, the money will have been well spent. 


\section{(This discussion applies also to the papers by Dr. H. Meredith Richinos and $\mathrm{Mr} . \mathrm{R}$. LishMaN.)}

Mr. A. F. Somervidue (Wells) said that, as representing a county education authority, and also as chairman of a county sauitary committee, he wished to say how very much he appreciated the papers read. He wished that rome resolution could have been passed calling the attention of comnty authorities to the question of hygiene, because one saw that there was a tendency, as had been pointed out by $\mathrm{Mr}$. Lishman, to re-introduce over-pressure. In the country, where they had to deal with boys and girls not so sharp as those in the towns, the curriculum set for the children often seemed absurd. The other day two girls, one the daughter of a labourer in his garden and the other the daughter of a gardener, were asked to describe a udometer. IJe limself did not know what a udometer was at that time. Shortly after at the annual meeting of the school he was asked to move a rote of thanks to the Bishop, who was presiding. The master of the school, in a very excellent speech, had said that the object of education was to teach children to think rather than to cram them with details. He (Mr. Somerville), in moving the vote of thanks, mentioned what had been expected of the girls, and, turning to the Bishop, said "Of course, my lord, you know what a ndomrter is?" "Never heard of one!" was the reply. There was not a single person in the school except the headmaster, and perbaps one or two of the teachers, who knew what the rord meant. It was, he believed, an instrument for ascertaining the amount of oxygen in the air. He thought what was winted in schools was a little more practical teaching. They wanted a wider basis and a freer hand given to comnty authorities. The question of hygiene was absoiutely necessiry, and although they all could not incur the expense of having medical officers for their schonls, they could at least train the staff of the school to pay more attention to the health and to the physical as well as to the mental eapacity of the scholars.

Counciluon Kexnedy (Southport) said that he spoke as a member of an education authority with unlimited responsibility and limited autlonity. The paper that had appealed most to him was the one by Dr. Richards. It was always a pleasure to members of comcils to be told what were their duties, and he noticed that Dr. Richards pointed out three. The first, he thought, was very good counsel. There were certain non-notifiable diseases, and for notification of these they were dependent upon voluntary action. He had expected some recommendation with regnul to these infections diseases. The avernge working class mother took the measles and the whooping-cough as a matter of course. In Southport they had made these, and also the chicken-pox, compulsorily notilialse, and they had had good results. He would like to have an expression of opinion from Dr. Riclards as to whetber in his opinion notification of these diseases ought not to be compuliory as well as of the others. 
Dr. Bromar (Bradford) sairl that he thought Miss Beszant's paper was a very important one. If her ideas were carried out they would have a beneficial effect upon the married life, especially of the poor. Most girls had, as a rule, no idea of household matters before marriage, and often made their homes uncomtortable and unhappy. Of course, the so-culled clever children were not always the most intelligent. They would very often find that a boy who was at the top of the class at school did not do well in after life, and if they read the history of geniuses they would find that they were often looked upon as dunces at school. There was a mistaken iden that schools were made for the clever children. Schools were made for the large number. He agreed with the remark $\mathrm{Mr}_{\mathrm{r}}$. Lishman made that the best masters ought to be reserved for the backward children. It would therefore be very unfair if the abilities of the master were judged by the successes of his children. A clever child ought to be kept back. The system of cramming was fatal. The chief thing was to teach the children to think and how to learn, because, as a matter of fact, what they did learn at school was not very much. 'They larnt a great deal more alter they left school.

Mr. W. Cuarluge (Chairman, Bradford School Board) said that it had been suggested that they should try and get some practical results from their Conterence. Dr. Richards suggested that children should not be compelled to attend school when suffering from or associated with disease. Payment by the Government, however, depeuded upon the attendance, and the consequence was that there was a bribe to attend. Cases of illness had been provided for by Article 101 in the old code. If infection broke ont the teachers did not try to force the children into the school, but by marking the child's name, as allowed by that regulation, they got the benefit of the attendance grant. He thought that they should recognise the need of baring Article 101 put back into the code. Coming to another practical point, he thouglit that they might do a great deal of good in sending an emphatic protest against the individual examination of children. He was sure that the case only required to be stated in order to be recognised. Another practical point in Miss Beszant's paper was that the teachers who were present, and who heard perhaps for the first time the things she had said, should try and introduce some of the adrantages she bad dealt with. The Bradford School Board were asking Miss Beszant to hold al class on Fridays and Saturdays, so that every teacher would have an opportunity of attending them during the coming winter. The Bradford School Board was very alive to the need for development on these lines, and its movement in that direction was very largely due to Miss Macmillan's influence. Now the work had been taken up earuestly by the School Board, and they were opening dissies in Green Lane. With regard to Dr. Richards" paper he would like to say that it would be better if that paper had been devoted to the secondary schools of the country. Ihis own experience was that the requirements of that paper bad been more 
or less met in elementary education, but with regard to secondary education they most decidedly had not been met. They would find secondary schools where the children were packed more or less like berrings in a box. T'he paper on hygiene, he thought, was of such immense value that it should be circulated broadcast. It was the best paper that he had listened to on that subject.

Mr. Thomas Garbute (Clerk to the Bradford Sehool Board) said that the question of making sure that childeen were physically tit before they began to attend schoul was, he thought, well met in the larger towns. With regard to notifiable diseases, his feeling was that if measles were added to the number it would be a step in the right direction. He was strongly of opinion that the apidemics of measles could easily be stamped out if the local authorities would pay the usual fees for notitication and discharge. Miss Beszant had told them Low far they conld go in training the teachers, and they should see that the teacher was taught to detect disease. He, as clerk of a school board, had a strong prejudice agaivst divided school medical authorities, i.e., the division of a district under separate local practitioners. Let there be one medical man specially appointed, and responsible for the whole of the schools in the district and give him such help as he may need. A proposal laad been made to haw. a daily visit from the doctor, but he thought that would have the effect of cansing a species of panic. A daily risit of a medical man or even a nursiog sister would be very injurious. It would operate prejudicially on the disciplin. of the school, and would make the parents themselves think that attendance at the schnols was injurious. He never heard of ringworm being sufficiently prevalent in any scbool to require the formation of a special class. Iff children suffering from ringworm conld be isolated and detained in all cases where they were neglected at home, speedy cures might be effected. In Bradford they had had one or two schools where it had been necessary to examine the children's heads, and he had been informed by parents on many occasions that the School Board appeared to have a very poor opinion of the parents of Bradford. No child could be admitted to a special school unless certified as suitable by the head teacher and by a medical wan, and afterwards examined in the presence of an inspector of the Board of Edncation. As regards the special classes in Bradford, when the teacher of an ordinary school reported a case, the doctor visited that case and reported to a committee; and the committee invited the parent to attend with the child at a meeting of the committee. The greatest moral suasion had to be brought to bear upon the parents to make them think that the child was not quite bright. He approved of the suggestion that the class rooms should be as bright as possible. In Bradford they were doing their best in this direction. With regard to Article 101*, the Bradford School Board had petitioned strongly in favour of its retention, but had so far only received a mere acknowledgment. He called attention to the last paragraph of Mr. Lishman's paper, which he thought should be emphasised. 
Mrs. KInK (Bradford) said that she thought that the teaching of hygiene should begin in the lowest class of the infant school, the baby class, not by means of rules, but by training the child in good babits. She that thought if there could be an improvement in the standard of work expected from infant teachers it would be a great assistance.

Mrr. Gutu (Bradford) said he thought that they need not form classes of children suffering from ringworm, which was on the decrease in Bradford. Local authorities, he thought, should do something with regard to children coming from infected homes. If the authorities would issue circulars asking the parents to keep such children at home, it would help. With regard to Miss Beszant's paper he was afraid she bad not come down to his level; at any rate the papers read would show that teachers were fully alive to the needs of the time. He did not think that any doctor was a bugbear in coming into schuol. They in Bradford had been heartily glad to see Dr. Kerr, and now they were glad to see his successor. As regarded the Bradford School Board, he did not think that there were many suggestions thrown out that morning that were not being put into practice in the Bradford schools. He regretted that the last spealier but one seemed to breathe a suggrestion of mistrust of teachers; he did not like the tone of the remarks at all. There were teachers to be found who would teach their subjects in a competent fashion. Individual examinations were looming in the air, and the teachers dreaded them and regretted it for the children's sake.

Dr. Crowler (Bradford) said that he thought that the teaching of hygiene should be carried out much more fully than at present. One could not help seeing the lack of the knowledge, even in Bradford, where considerable attention was paid to the subject in the higher grade schools. One of the teachers actually told him that he did not like to open the windows because the children got the mumps! Occasionally he asked of the pupil teachers the question: "How many times does your heart beat in a minute?" and "How many times do you breathe in a minute?" and he frequently got an incorrect answer. The teaching of bygiene in the ordinary schools could only be done in the course of the ordinary curriculum. In the pist medical officers of health had been men who had not had the benefit of practical school work, and he rentured to say that their recommendations must sometimes be received with caution. In Bradford, though the establishment of special classes for ringworm children was certainly not necessary, yet he thought they could limit the number of cases even more than at present, by appointing one or two nurses to visit among the schools. They had about fifty children absent on account of ringworm, and about fifty more on account of the dirty state of their heads.

The President (Dr. J. Kerr) said that several important points had bern brought forth. It appeared to him that the necessity for hygienic training in 
schools had been well emphasised. In the infant department proper labits could be shaped. At present be was considering whether or not they should have ringworm schools. As Dr. Crowley had said, there were not many cases of ringworm in Bradford but there were parts where it was very serious. Then the question of Article 101\% was almost one of high politics. It was so important that, although no resolution had been made, he proposed reading one from the chair and sending it forward.

Miss Beszant, in replying on the discussion, said that the object she had in reading the paper was not to teach teachers, but that she thought it her duty to show the people of Bradford what the Bradford School Board had done in the way of teaching hygiene. It was not always the Board of Education that had failed. It was often a question of economy. In many secondary mixed clisses it was economical to employ a man to teach physics and chemistry rather than physics to the boys and hygiene to the girls. Physiology and hygiene had been very badly tanght, and inspectors had been afraid to advise that they should be taught to girls. An inspector had once said to ber, "You cannot teach physiology and hygiene and make it an educational subject like physics and chemistry." She replied "if you will allow me to experiment I will prove to you that it can be done." She referred to Mr. Wager, H.M.I. of Secondary Schools, and he had belped her, with the result that it had been pronounced by the inspectors to be satisfactory. With regard to the formation of babits she found it satisfactory to make scholars responsible for the opening of windows and for the tidiness of the class rooms. She would like to empbasise the fact that the habits of the teachers could be improved, especially in regard to the stopping in the class room to dinner instead of getting out into the fresh air. They stopped often enough to gossip. She would also like to emphasise the fact that the head teachers should teach the others not to drink so much tea as they did. In her paper she especially wanted not to talk from the standpoint of the secondary school. In the elementary part of their school they taught elementary science applicable to board schools. There was no elaborate apparatus necessary, so that there was no necessity for the teacher to postpone making a start.

Mr. Lismun saicl that it was a well known fact that the majority of the Oxford and Cambridge senior wranglers never distinguished themselves in after life. With the abolition of payment by results the elementary teachers had been able to extend the curriculum of their schools. He had no belief in the dictum that they ought to teach a little and teach it well. At present a chance was given to every boy to distinguish himself in the branch for which he was best fitted, but under the old plan many boys had no chance of distinguishing themselves. Many of the so-called dufters were incipient engineers or inventors. He believed, therefore, in a wide curriculum. In order to really train the children they wanted to be careful in the appointment of teachers. Having 
done that, the inspectors ought to confine themselves entirely to criticism of methods of teaching and not to examination of results. If the methods were good the results would be good, but if they were bad they could only bave bad results. They could, however, get speciously good results from bad methods. In his paper he mentioned as an example of this how in drawing, under the old scheme of South Kiensington, utterly vicious methods were used.

Dr. Ricmarns (Croydon) said that he was pleased to hear from Dr. Kennedy that in Southport the compulsory notification of measles had, so far, worked satisfactorily, but there were objections to the universal application of that system. School notitications gave medical officers an opportunity of visiting the parents and educating them in the treatment of the so-called minor diseases. The objections raised to the formation of special classes for ringworm had been answered by the President. Circumstances differed in various parts of the country. In the neighbourhood of London ringworm was a serious matter, as cases were numerous and entailed absence from school for from three to six months. He assured Mr. Garbutt that his strictures on insanitary schools did not apply to the schools provided by progressive autborities like Bradford. It was a fact, however, that in various parts of the country schools with grave sanitary defects were far too common. The question of dirty beads was a disagreeable onc. Hospital experience showed how widespread the trouble was. At present only the most obvious cases were excluded from school. More stringent regulations and greater care were necessary in dealing with these cases. He was extremely interested in Miss Beszant's paper, but he did not think that hygiene could be taught in elementary schools in the thorough manner suggested. He fenred teachers would find few children under thirteen sears of age sufficiently developed to benefit from such instruction. He thought, therefore, that school hygiene should be taught in the concrete manner suggested in his paper. To enable this to be done, it was of course essential that every teacher should be thoroughly grounded in hygiene.

Tire Presinexis (Dr. J. Kerr) then moved that this Conference of The Sanitary Institute on the Hygiene of School Life suggests the desirability of re-inserting the code regulations for payment of grant under Section 101* in cases where absence is due to epidemic disense, as this bas been a sanitary influence of great practical use in the past.

Mr. Cramidge seconded the resolution, and it was carried.

Notw.-Resolutions passed at meetings of the Institute can only be in the form of recommenditions to the Council, to whom they must be submitted for consideration and approved before they can be considered as the official opinion of the Institute.

Notes of the decisions of the Council on the resolutions are given at p. 855 . 